\title{
ARF to remain the same for 2022
}

In what continue to be uncertain times for the dental sector, a Council meeting of the General Dental Council (GDC) set its budget for 2022 and, in doing so, confirmed the Annual Retention Fee (ARF) will remain the same next year.

Almost all of the GDC's income is generated by the fee, which all dental professionals pay to retain their registration. With such a high level of uncertainty and risk regarding both the organisation's income and required expenditure over the next 12 months, the decisions were taken 'to guarantee the regulator will be able to fulfil its core purpose of ensuring patient safety and maintaining public confidence in the professions'.

Council approved an increase of $4.1 \%$ in the operating budget, which equates to $£ 39.7$ million for the year. This follows the reduction of $6.5 \%$ the previous year.
BDA AGMS
The BDA Northern
Counties Branch AGM will
be held online on Tuesday
7 December 2021 at 7 pm.
The BDA East Midland
Branch AGM will be held online on
Wednesday 12 January 2022 at 7.30 pm.
Please ensure you register your
interest in attending either event at
www.bda.org/bse in order to receive
the link to access the AGM, or email
branchsectionevents@bda.org.

\section{BOOK REVIEW}

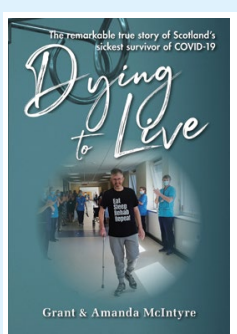

\section{DYING TO LIVE, THE STORY OF GRANT MCINTYRE, COVID'S SICKEST PATIENT}

Grant and Amanda McIntyre;

2021; Tippermuir Books Ltd; price f9.99; pp. 228;

ISBN: 9781913836092

The words 'near-death experience' are suggestive of a horrifying event lasting just a few minutes yet having a lifelong psychological impact. Consultant orthodontist Grant McIntyre had a near-death experience which lasted 50 gruelling days. The cause was COVID-19 and, after four months in hospital, Grant was to become known as Scotland's sickest survivor. The extraordinary story of the time he spent at death's door while his medical team fought to keep him alive is told with searing honesty in the book he has written with his wife, Amanda.

When he became ill in March 2020, Grant was a Professor of Orthodontics and Clinical Director at Dundee Dental Research Hospital and School, and, irony of ironies, one of the senior leadership team preparing for a possible influx of COVID-19 patients.

He thought initially he was suffering from a bad dose of influenza. Struggling to breathe, he was admitted to Dundee's Ninewells Hospital but sent home the next day, before being admitted twice more, his health declining all the time. Finally, he was diagnosed with severe viral pneumonia, brought on by COVID-19. He vividly recalls saying to the consultant: 'I think I am going to die. Please save my life'.
Grant asked the Consultant for CPAP (continuous positive airway pressure) but already needed a more drastic intervention; he remembers only the start of the anaesthetic as he slipped out of consciousness and into a deep sedation. He was connected to a ventilator, along with an arterial line, a central venous line, a nasogastric tube and a catheter. Initially stable, he crashed into critical illness.

While COVID-19 was the trigger for his ill health, he became seriously ill due to an exaggerated inflammatory response, which led to kidney and liver failure, sepsis, a brain haemorrhage, two pulmonary embolisms and a collapsed lung. His doctors decided on a last-ditch solution to keep him alive and this was ECMO (extra corporeal membrane oxygenation), which provides life support for coronavirus patients suffering respiratory failure. For a time, he was moved to Aberdeen Royal Infirmary, and it was there that his journey back from death's door finally began.

This is a thoughtful read. In addition to Grant's personal story, the book provides the history of COVID-19 set in the context of other viruses. The carefully planned structure and modulating pace prevents the reader from being overwhelmed by the uncomfortable medical detail. Although Grant clearly feels emotional, he is devoid of self-pity, the prose is unembroidered, and the account is cogent and direct. The chapters he devotes to his recovery, learning to walk and talk again as well as catch up with the news, are fascinating. Along with his physical health, his psychological state needed addressing. How surreal that in his delusional state he believed that he was George Floyd and the nurses caring for him were police officers kneeling on his chest, but this was all part of the anxiety and paranoia he suffered, the inevitable side effects of his treatment.

When Grant was innocently involved in COVID preparations four months earlier, those people expected to be worst affected were the elderly and the immunocompromised. Grant was 49 , fit and healthy. Why was he so badly afflicted? The only possible clue perhaps was that he had kept bees and suffered a bad reaction after being stung. Was this a sign that his body does not react well to attack?

I feel fortunate to have read this illuminating story of one man's epic journey back to life as well as to hear his presentation at the British Orthodontic Conference, culminating in a standing ovation. We all need to know and understand the impact of COVID so we do not lapse into carelessness.

The psychological impact of Grant's neardeath experience and of being Scotland's sickest survivor will be with him for life but fortunately for his readers, Grant's appetite for getting on with the rest of his life, and enjoying every minute, is inspirational.

By Caroline Holland 